\title{
New method for edges detection of magnetic sources using logistic function
}

\author{
L. T. Pham ${ }^{1}$, E. Oksum ${ }^{2}$, T. D. Do ${ }^{1}$, M. L. Huy ${ }^{3}, 2018$ \\ ${ }^{1}$ VNU University of Science, Faculty of Physics, Department of Geophysics, \\ Hanoi, Vietnam \\ ${ }^{2}$ Süleyman Demirel University, Engineering Faculty, \\ Department of Geophyisical Engineering, Isparta, Turkey \\ ${ }^{3}$ Institute of Geophysics, Vietnam Academy of Science and Technology, \\ Hanoi, Vietnam \\ Received 31 July 2018
}

\begin{abstract}
Кут нахилу амплітуди аналітичного сигналу (ТА) визначають як арктангенс відношення першої похідної вертикального градієнта до сумарної горизонтальної похідної амплітуди аналітичного сигналу. Визначення цього кута зазвичай використовують як корисний метод Аля оцінювання граней магнітних Ажерел, оскільки його величина незначно залежить від напрямку намагніченості. За аналітичною функцією $(L)$, що має однакову форму з формою функції арктангенсу, введено деякі нові фільтри, які також можуть зменшити ефект напрямку намагніченості. Крім того, ці фільтри створюють амплітудні максимуми над межами джерел і компенсують вплив аномалій від незначних і глибоких джерел. Можливість використання фільтрів продемонстровано на чистій і спотвореній шумами синтетичних 3D магнітних моделях, коли отримані положення граней добре збігаються з реальними межами. Ефективність фільтрів оцінено також порівнянням їх з даними інших методів виявлення положення граней. Показано, що нові фрільтри менш чутливі до варіацій глибини розташування джерела тіл і що використання модифікованої логістичної функції $\left(L_{k}\right)$ може забезпечити кращі результати, ніж амплітуда аналітичного сигналу (AS), амплітуда аналітичного сигналу кута нахилу (АТ), TA- і $L$-рільтри. Фільтри також застосовують до магнітних даних ділянки на півдні центрального В'єтнаму. Запропоновані фільтри є корисним інструментом для якісної інтерпретації магнітних спостережень.
\end{abstract}

Ключові слова: логістична функція, кут нахилу, амплітуда аналітичного сигналу, визначення граней, інтерпретація магнітних даних.

Introduction. Edge detection is an important field in magnetic interpretation. There are many methods for detecting edges, most of which are based on the vertical or horizontal derivatives of the field. The most commonly used filter is the total horizontal derivative of the potential field [Cordell, 1979; Cordell, Grauch, 1985]. The greatest advantage of this filter is its low sensitivity to the noise in the data because it only requires the first order horizontal derivatives of the field. However, the filter requires a reduction to the pole or pseudo-gravity transformation [Cordell, Grauch, 1985] that has serious limitations when used in low latitude areas. Furthermore, the edge detection result is dominated by the response from the shallower sources that produce strong anomalies, and hence it cannot display the strong and weak amplitude anomaly edges simultaneously [Cooper, Cowan, 2008]. In order to make both the shallow and deep sources visible simultaneously, [Miller, Singh, 1994] proposed using tilt angle that based on the 
ratio of vertical derivative to total horizontal derivative, [Cooper, Cowan, 2006] used horizontal tilt angle, and [Wijns et al., 2005] used the theta map method. However, all three methods are sensitive to dip and magnetization effects [Pilkington, Tschirhart, 2017]. Another method which is also based on tilt angle is introduced by [Verduzco et al., 2004], called total horizontal derivative of tilt angle. Although the method is not influenced by dip or magnetization effects, it generates some false edges [Pilkington, Tschirhart, 2017]. Another commonly used method, known as the analytic signal amplitude method, is introduced by [Nabighian, 1972] and [Roest et al., 1992]. They showed that, in the 2D case, the shape of the analytic signal amplitude is independent of the direction of the ambient magnetic field and the direction of source magnetization. However, [Li, 2006] pointed that this independent is lost in the 3D case. An enhanced analytic signal is introduced by [Hsu et al., 1996]. They used the higher order derivatives to detect the edges of magnetic sources. Although the method can effectively reduce the interference due to adjacent geological bodies, the effect of noise increases. Another disadvantage of the method is that it cannot display large and small amplitude edges simultaneously. [Ansari, Alamdar, 2011] suggested the use of the analytic signal amplitude of the tilt angle as a balanced edge detection filter. It is more effective than the analytic signal, but it still performs poorly in detecting all the edges of the body [Cooper, 2014]. G. Cooper proposed modified analytic signal amplitude that based on tilt angle method to balance the different amplitude edges. The advantage of the method is reducing the dependence of the analytic signal amplitude of magnetic anomaly on the direction of magnetization.

In this paper, we describe a new edge detection filter based on the logistic function. We also improve this by introducing a modified logistic function resulting as an enhancement in delineating the geologic contacts.

Theory. The analytic signal of magnetic anomaly $\mathrm{M}$ is defined in 3D by [Roest et al., 1992] as

$$
A S(x, y)=\frac{\partial M}{\partial x} \hat{x}+\frac{\partial M}{\partial y} \hat{y}+i \frac{\partial M}{\partial z} \hat{z}
$$

where $i=\sqrt{-1}$ and $\hat{x}, \hat{y}$ and $\hat{z}$ are unit vectors in $x, y$ and $z$ directions, respectively. From Eq. 1 it follows that the amplitude of the analytic signal is given by:

$$
|A S(x, y)|=\sqrt{\left(\frac{\partial M}{\partial x}\right)^{2}+\left(\frac{\partial M}{\partial y}\right)^{2}+\left(\frac{\partial M}{\partial z}\right)^{2}} .
$$

The ratio of the first vertical derivative and total horizontal derivatives of the analytic signal amplitude is:

$$
R=\frac{\frac{\partial A S}{\partial z}}{\sqrt{\left(\frac{\partial A S}{\partial x}\right)^{2}+\left(\frac{\partial A S}{\partial y}\right)^{2}}}
$$

G. Cooper used arctangent of $\mathrm{R}$ to delineate the edges of the magnetic sources, called it the tilt angle of analytic signal amplitude (TA) [Cooper, 2014]. He showed that the TA is theoretically independent of the source magnetization vector direction for the 2D case, and it can reduce the effect of the magnetization direction for the 3D case. The TA filter is sensitive to the noise in the data because it uses second order derivatives, and especially the ones that use vertical derivative. To reduce the noise effect, [Cooper, 2014] proposed using the zero order analytical signal amplitude. Although this filter has a much reduced noise sensitivity, the edges of the magnetic sources are not as sharply defined. Here, we introduce a new filter based on logistic function and the ratio of the first vertical derivative and total horizontal derivatives of the AS, which is defined as

$$
L=\frac{1}{1+e^{-R}}
$$

The idea of producing this filter is that logistic function is a mathematical function having a characteristic «S»-shaped curve (or sigmoid curve) that is the same shape with the shape of arctangent function. 
Therefore, it also can reduce the effect of the magnetization direction, like the TA filter. Similarly to the tilt angle of analytic signal amplitude, using logistic function leads to a more balanced response. Both methods are effective in enhancing the edges that produce only low-amplitude analytic signal maxima. Nonetheless, the edges of the shallow source are clear and refined, whereas the edges of deep source are clear but diffuse. In this study, we resolved this issue of the logistic filter by using a modified logistic function, which is defined as

$$
L_{k}=\frac{1}{k+e^{-R}}
$$

Where $k$ is a positive constant less than one.

In order to demonstrate the feasibility of $L$ and $L_{k}$ filters, we choose three other frequently used filters to compare the boundary detection results. They are the AS, the AT and the TA.

Synthetic Example. The efficiency of the new methods to enhance the detection of edges of the magnetic source bodies is studied by analysis of two synthetic examples. The first example involves a single prism with parameters shown in Table 1.

Fig. 1, $a$ shows the magnetic anomaly due to the single prism model whose outlines are shown in black. The results of AS, AT, TA, L, and $L_{k}$ of the field are shown in Fig. $1, b-f$ respectively. It can be observed that the AS is only effective in enhancing two of the four edges of the causative body. The AT is more effective than the AS in enhancing all the edges of the causative body. However, the edges detected by the AT are not precise, and it is clearly noisier than the other filters. Both the L and the TA yield similar results, they enhance all the edges, yet their obtained results are diffused to some extent. By comparison among the results in Fig. 1, we can see that $L_{k}$ can not only delineate the edges of the source body clearly and precisely, but also give better resolution of the edges than other filters.
The second example involves three prisms models with the same dimensions in size but in increasing depths. Their parameters are shown in Table 2. The outlines in plain view of the prismatic sources are shown by the black lines in all figures. In order to test the stability of the $L$ and $L_{k}$ filters, we added random noise with amplitude equal to $5 \%$ of the data amplitude to the magnetic anomaly data due to the prisms (Fig. 2). Because the $L$ filter uses second order derivatives which increase the noise influence. Therefore, we need to reduce the noise effect first before we use the filter to detect the edges. Using upward continuation of the magnetic data, the noise effect can be reduced. Fig. $2, b-f$ display the results of the AS, AT, TA, L and $L_{k}$ after upward continuation of $1 \mathrm{~km}$, respectively. In this case, as can be seen from Fig. $2, b, c$, the AS is also only effective in delineating two of the four edges of each causative body, whereas the AT represents a poor view of the edges. Fig. 2, $d$ shows the results calculated by the TA filter and Fig. 2, $e$ is the results from the application of the $\mathrm{L}$ filter. It can be observed that the TA and the L filters can enhance all the edges of causative bodies. The edges are clearly enhanced more sharply, compared with AS and AT filters. Fig. $2, f$ displays the edges detected by the $L_{k}$ filter. It can be clearly observed that the $L_{k}$ filter can not only balance anomalies from shallow and deep sources, but also give a higher resolution, and can delineate the edges more clearly and precisely. The amplitude of the response from the two causative bodies is similar, although the response from the deeper causative body is rather diffuse.

Real Data Example. In order to demonstrate the practical applicability of the suggested new filters, we consider their applica-

Ta b le 1. Parameters of the single prism model

\begin{tabular}{|c|c|c|c|}
\hline Center coordinates & $31.5 \mathrm{~km} ; 31.5 \mathrm{~km}$ & Length $\times$ Width & $30 \times 30 \mathrm{~km}$ \\
\hline Inclination & $15^{\circ}$ & Depth of top & $2 \mathrm{~km}$ \\
\hline Declination & $25^{\circ}$ & Depth of bottom & $3.5 \mathrm{~km}$ \\
\hline Magnetization & $5 \mathrm{~A} / \mathrm{m}$ & Rotation angle & $0^{\circ}$ \\
\hline
\end{tabular}




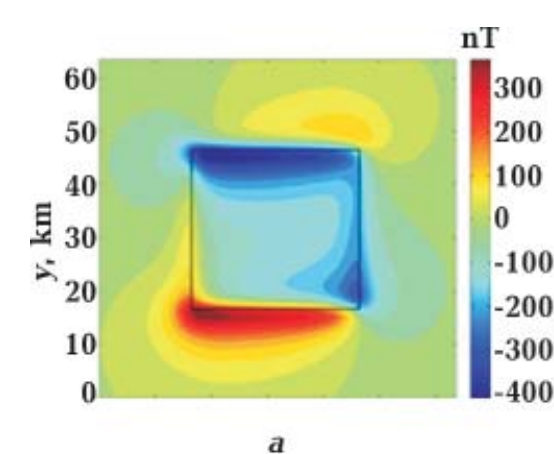

a

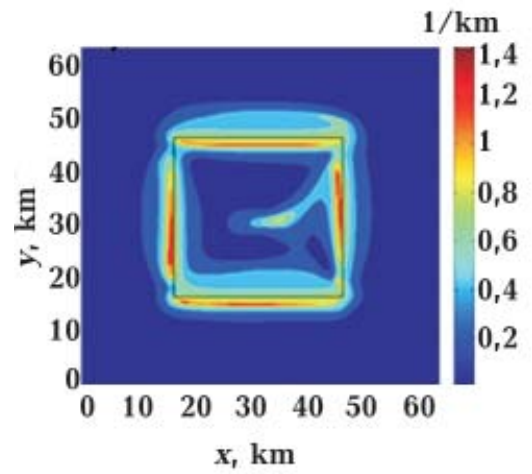

$d$

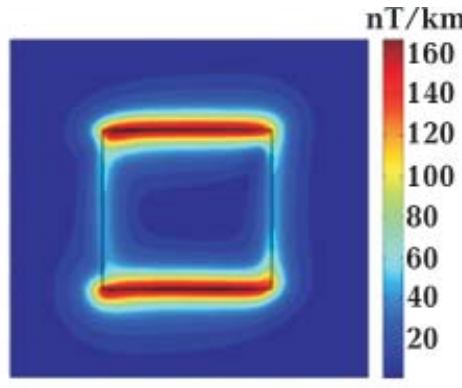

b

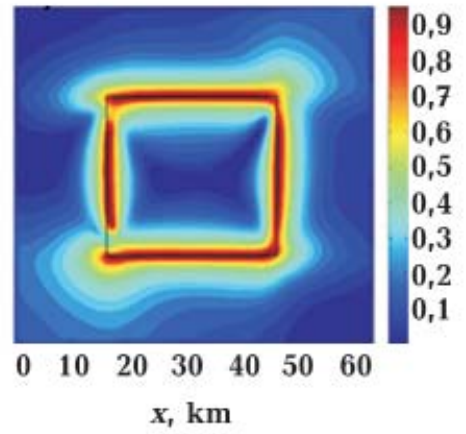

e

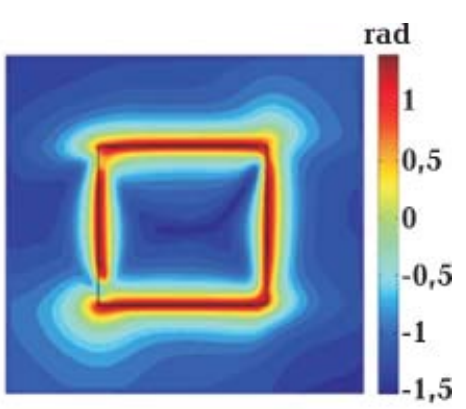

C

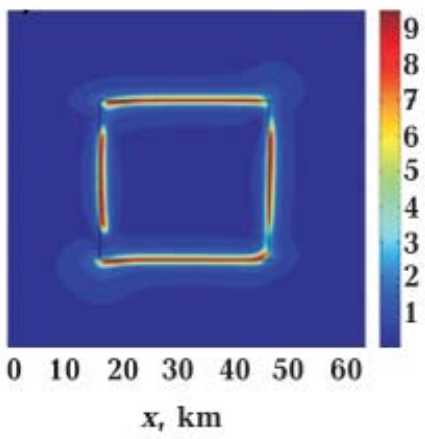

$\boldsymbol{f}$

Fig. 1. Test results of the single prism model (see Table 1): $a$ - synthetic magnetic anomaly of the single prism model, $b-\mathrm{AS}, c-\mathrm{AT}, d-\mathrm{TA}, e-L, f-L_{k^{\prime}}$ with $k=0.01$.

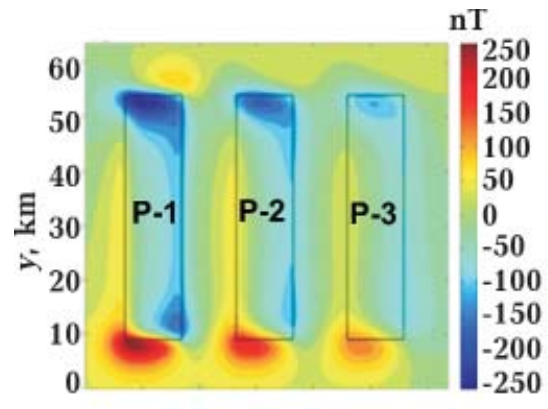

a

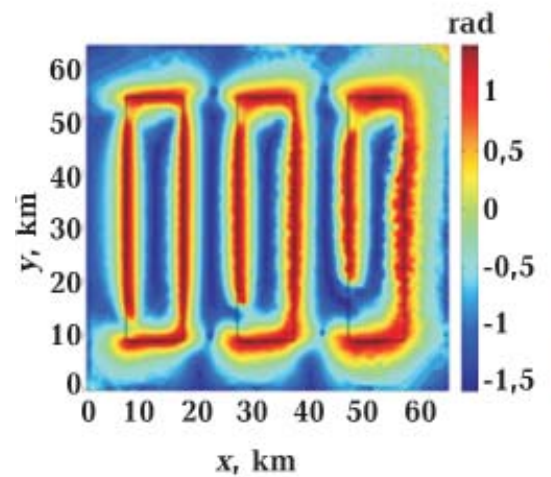

$\boldsymbol{d}$

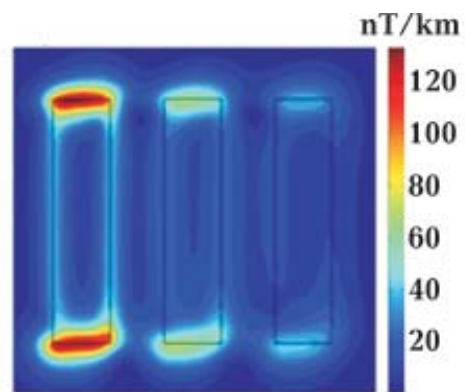

b

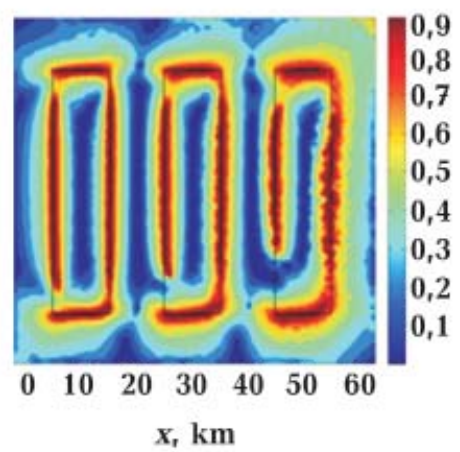

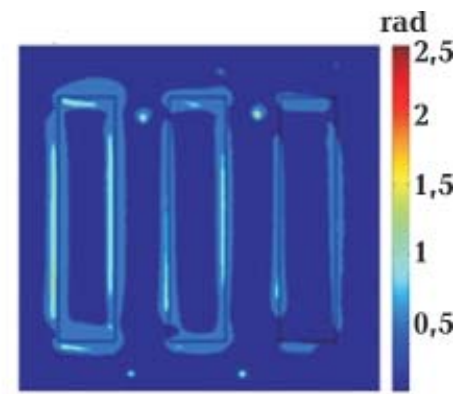

$C$

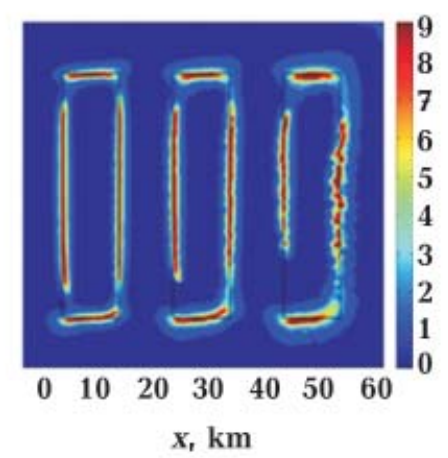

$\boldsymbol{f}$

Fig. 2. Test results of the three prism models P-1-3: $a-$ synthetic magnetic anomaly of three prisms, $b-\mathrm{AS}, c-$ $\mathrm{AT}, d-\mathrm{TA}, e-L, f-L_{k}$ with $k=0.01$. 

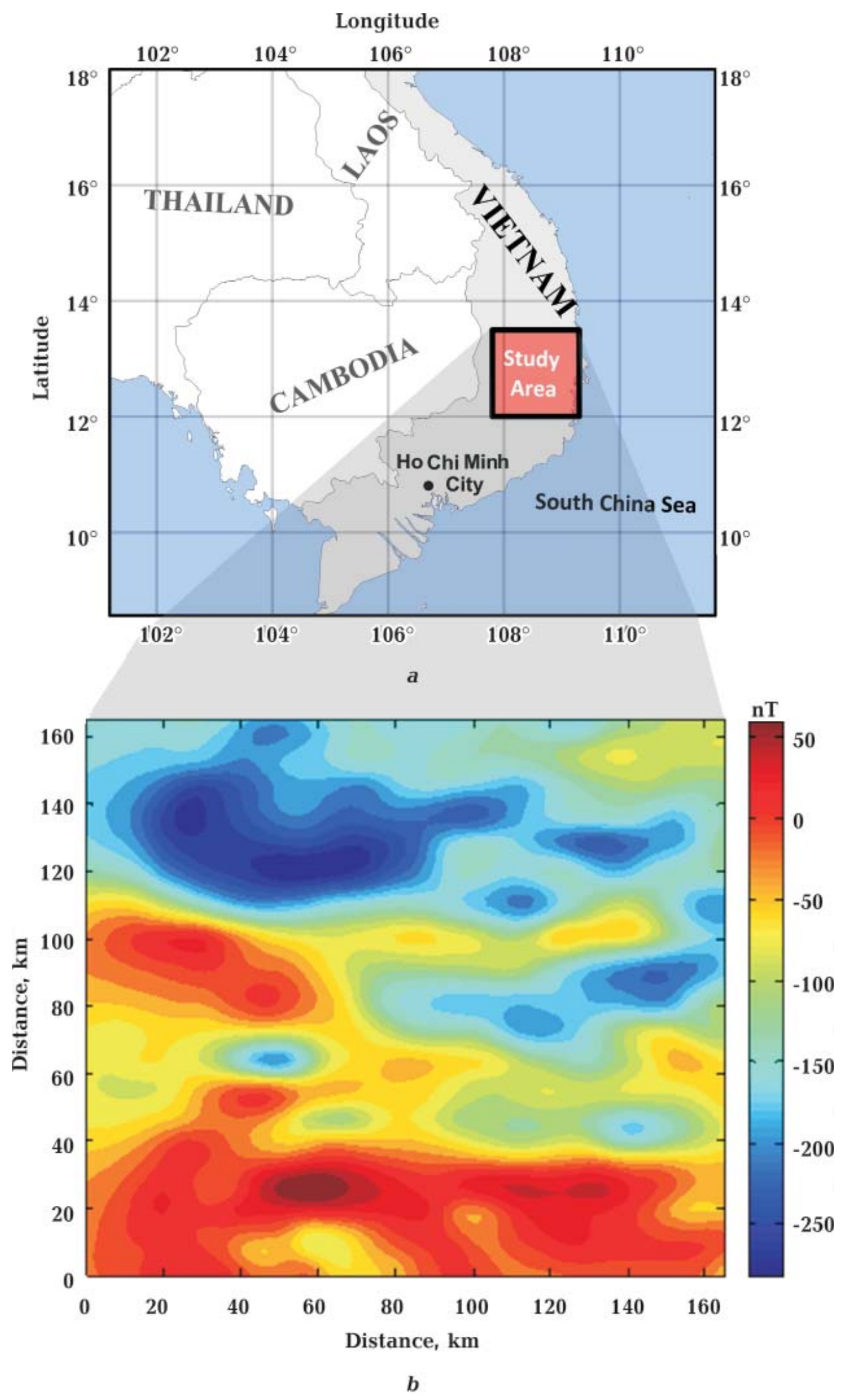

Fig. 3. Location of the study area within $(a)$, the total field magnetic anomaly of the study area (b). 

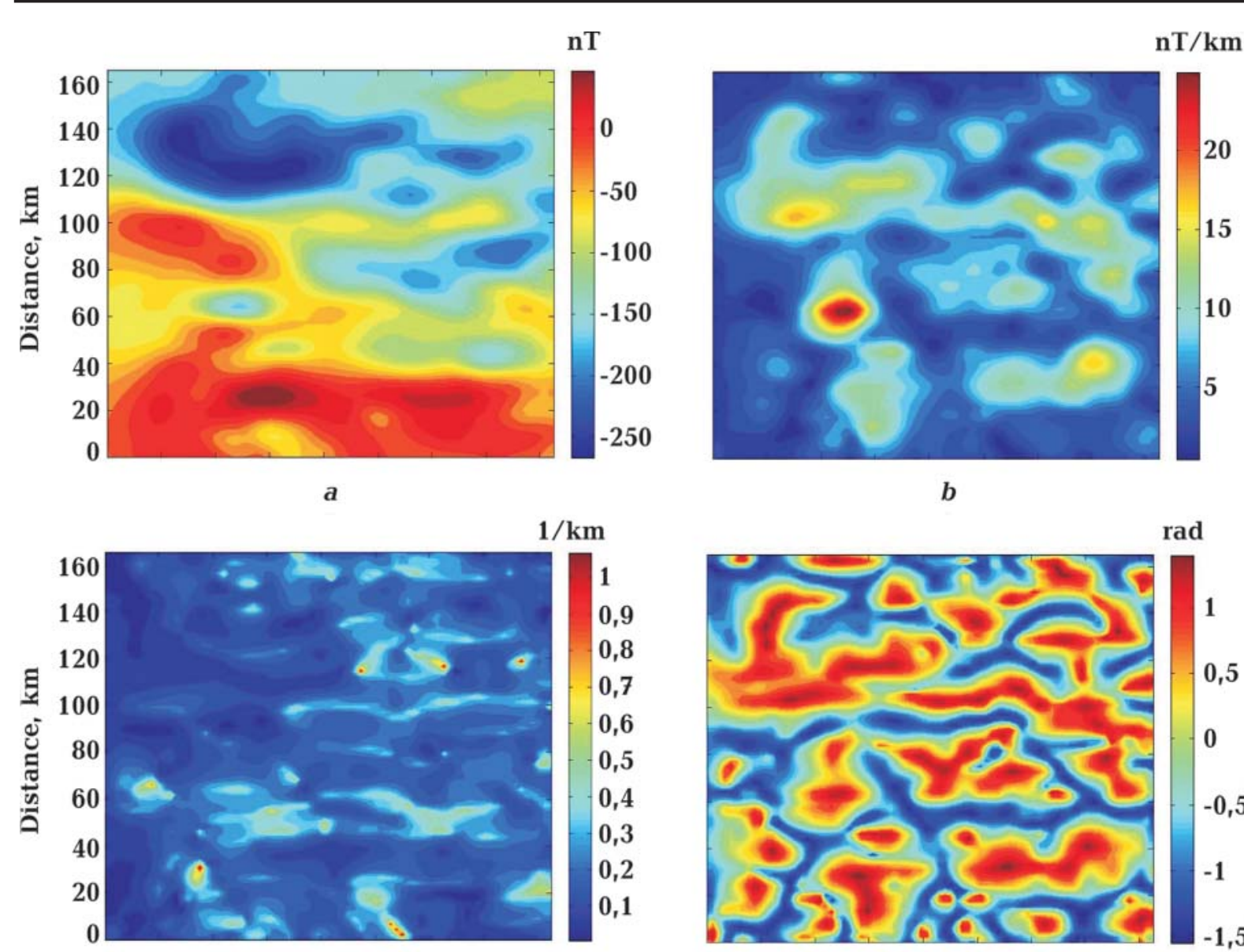

C

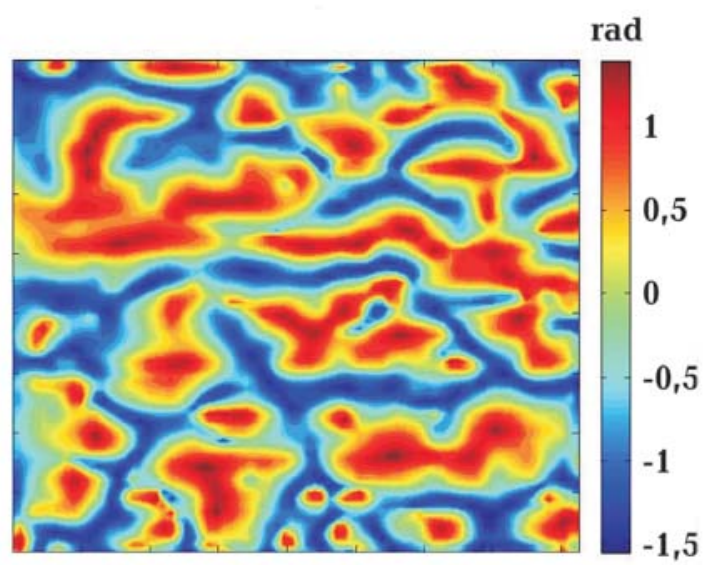

$d$

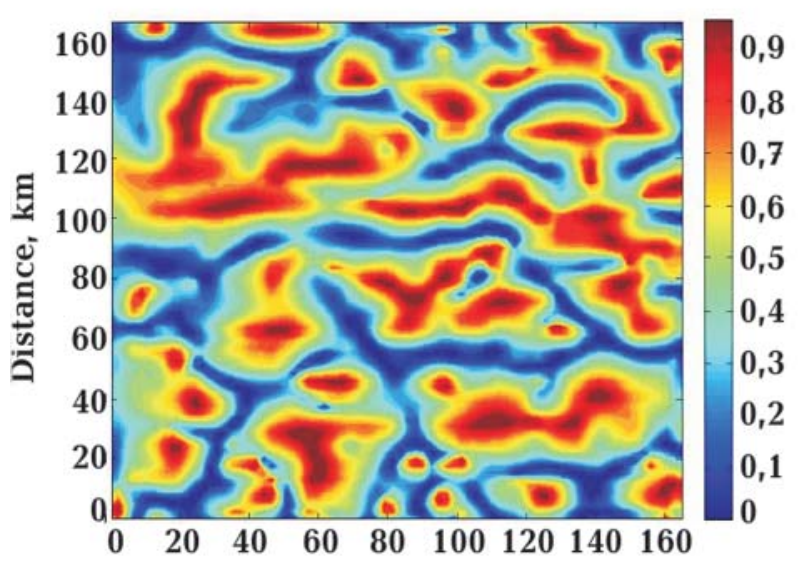

Distance, km

e

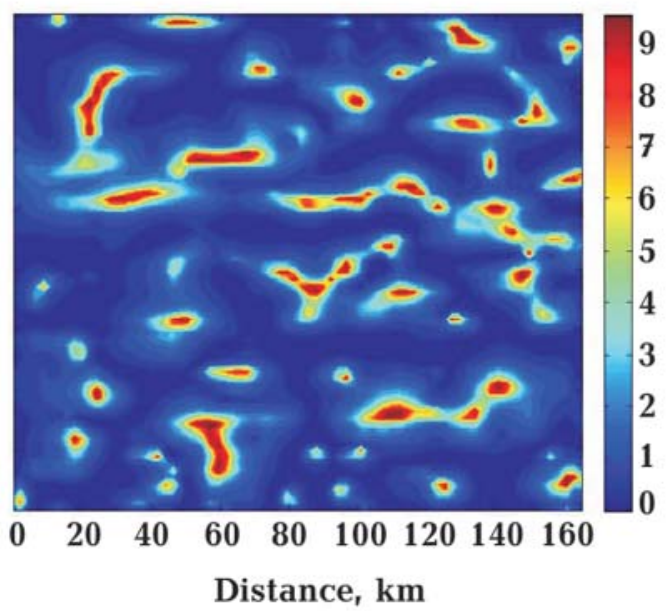

$f$

Fig. 4. The total field magnetic anomaly at upward continuation level of $1 \mathrm{~km}(a), b-\mathrm{AS}, c-\mathrm{AT}, d-\mathrm{TA}, e-L$, $f-L_{k^{\prime}}$ with $k=0.01$.

tion to field magnetic data from an area in south-central Vietnam. The study area lies between longitude $107.8^{\circ} \mathrm{E}$ and $109.3^{\circ} \mathrm{E}$ and latitude $12^{\circ} \mathrm{N}$ and $13.5^{\circ} \mathrm{N}$, covering an area of approximately $27000 \mathrm{~km}^{2}$ (Fig. 3, a). The total field magnetic anomaly data (Fig. $3, b$ ) are 
Ta b le 2. Parameters of the three prism model

\begin{tabular}{|c|c|c|c|}
\hline Prism ID & P-1 & P-2 & P-3 \\
\hline Center coordinates & $12 \mathrm{~km} ; 31.5 \mathrm{~km}$ & $31.5 \mathrm{~km} ; 31.5 \mathrm{~km}$ & $51 \mathrm{~km} ; 31.5 \mathrm{~km}$ \\
\hline Inclination & $12^{\circ}$ & $18^{\circ}$ & $20^{\circ}$ \\
\hline Declination & $25^{\circ}$ & $26^{\circ}$ & $24^{\circ}$ \\
\hline Magnetization & $5 \mathrm{~A} / \mathrm{m}$ & $5 \mathrm{~A} / \mathrm{m}$ & $5 \mathrm{~A} / \mathrm{m}$ \\
\hline Length $\times$ Width & $45 \times 10 \mathrm{~km}$ & $45 \times 10 \mathrm{~km}$ & $45 \times 10 \mathrm{~km}$ \\
\hline Depth of the top & $1 \mathrm{~km}$ & $2 \mathrm{~km}$ & $3 \mathrm{~km}$ \\
\hline Depth of the bottom & $2 \mathrm{~km}$ & $3 \mathrm{~km}$ & $4 \mathrm{~km}$ \\
\hline Rotation angle & $0^{\circ}$ & $0^{\circ}$ & $0^{\circ}$ \\
\hline
\end{tabular}

compiled by Geological Survey of Japan and Coordinating Committee for coastal and offshore geoscience programs in East and Southeast Asia [Geological ..., 1996]. The magnetic anomaly values vary from -280 to $+50 \mathrm{nT}$ with many positive and negative anomalies that have E-W trends. As a pre-process of the data, upward continuation of the total field magnetic anomaly was performed to reduce noise effect (Fig. 4, a). The upward continuation height used is $1 \mathrm{~km}$. The upward continuation produced results that are smoother and less sensitive to random noise than the original anomaly data, but will not change the primary shapes.

Fig. $4, b$ shows the AS of the magnetic data in Fig. 4, $a$. We can see that the AS filter performs poor, and it is dominated by the high amplitude anomalies. Fig. 4, $c$ shows the AT of the magnetic data. As expected (and discussed in the above sections), it is clearly more noisy than the results of using other filters, and it gives insufficient results to ac- curately determine the boundary of the magnetic sources. Fig. 4, $d$ and $e$ show the TA and $L$, respectively. By comparing the results, we can see that the TA and FS filters provided similar results, and they are effective in bringing out the details of the small amplitude anomalies. Fig. 4. $f$ displays the results of the $L_{k}$ filter. It can be observed from this figure that the $L_{k}$ filter cannot only balance the large and small amplitude anomalies, but provides the best resolution of the magnetic boundaries in the study area.

Conclusions. We have presented two new edge detection filters that are based on logistic function and the ratio of the first vertical derivative and total horizontal derivatives of the analytic signal amplitude. As in the tilt angle of analytic signal, the $\mathrm{L}$ and $L_{k}$ filters can be applied directly to the magnetic data. The disadvantage of the filters is that they are sensitive to noise. Using upward continuation of magnetic data can help reduce the effects of noise, and increase the coherency of the solutions. The filters have been demonstrated on two synthetics and real magnetic data. The results showed that both the $\mathrm{L}$ and $L_{k}$ filters can balance the large and small amplitude edges, and can bring out more details than the AS and AT filters. The results also showed that the $L_{k}$ filter give a higher resolution, compared with other edge detection filters.

\section{New method for edges detection of magnetic sources using logistic function}

\section{T. Pham ${ }^{1}$, E. Oksum ${ }^{2}$, T. D. Do ${ }^{1}$, M. L. Huy ${ }^{3}, 2018$}

The tilt angle of the analytic signal amplitude (TA) is defined as the arctangent of the ratio of the first vertical derivative to the total horizontal derivative of the analytic signal amplitude. It is commonly used as a useful tool to estimate edges of magnetic sources 
because its value is slightly dependence on the direction of magnetization vector, and it is more effective in estimating the edges of the bodies than the analytic signal amplitude and the standard tilt angle. Based on logistic function $(L)$ that has the same shape with the shape of arctangent function, and the derivatives of the analytic signal amplitude, we introduce some new filters which also can reduce the effect of the magnetization direction. Other notable features of these filters are that they produce amplitude maxima over the edges of sources and that they balance anomalies from shallow and deep sources. The feasibility of the proposed filters is demonstrated on noise-free and noisy synthetic magnetic data from two 3D models where the obtained results coincide well with the actual edges. The effectiveness of the filters is also evaluated by comparing it with other edge detection methods. The results also show that our filters are less sensitive to variations in the depth of the source bodies and that a modified logistic function $\left(L_{k}\right)$ can achieve better edge detection results than the analytic signal amplitude (AS), the analytic signal amplitude of the tilt angle (AT), the TA and L filters. The filters are also applied to real magnetic data from an area in south-central Vietnam, and the results demonstrate that the proposed filters is a useful tool for the qualitative interpretation of magnetic data.

Key words: logistic function, tilt angle, analytic signal amplitude, edge detection, interpretation of magnetic data.

\section{References}

Ansari, A. H., \& Alamdar, K. (2011). A new edge detection method based on the analytic signal of tilt angle (ASTA) for magnetic and gravity anomalies. Iranian Journal of Science and Technology, 35(2), 81—88. doi: 10.22099/ ijsts.2011.2131.

Cooper, G. R. J. (2014). Reducing the dependence of the analytic signal amplitude of aeromagnetic data on the source vector direction. Geophys iCS, 79(4), J55-J60. https://doi.org/10.1190/ geo2013-0319.1.

Cooper, G. R. J., \& Cowan, D. R. (2008). Edge enhancement of potential-field data using normalized statistics. Geophysics, 73(3), H1- H4. https://doi.org/10.1190/1.2837309.

Cooper, G. R. J., \& Cowan, D. R. (2006). Enhancing Potential Field Data Using Filters Based on the Local Phase. Computers \& Geosciences, 32(10), 1585-1591. https://doi.org/10.1016/j. cageo.2006.02.016.

Cordell, L. (1979). Gravimetric Expression of graben faulting in Santa Fe Country and the Espanola Basin, New Mexico. In R. V. Ingersoll (Ed.), Guidebook to Santa Fe Country (pp. 59 -64). New Mexico Geological Society, Socorro.

Cordell, L., \& Grauch, V. J. S. (1985). Mapping
Basement Magnetization Zones from Aeromagnetic Data in the San Juan Basin, New Mexico. In The Utility of Regional Gravity and Magnetic Anomaly Maps (pp. 181-197). Society of Exploration Geophysicists, Tulsa.

Geological Survey of Japan and Coordinating Committee for Coastal and Offshore Geoscience Programs in East and Southeast Asia (CCOP). (1996). Magnetic anomaly map of East Asia 1:4 000 000. CD-ROM.

Hsu, S. K., Coppense, D., \& Shyu, C. T. (1996). Highresolution detection of geologic boundaries from potential field anomalies: An enhanced analytic signal technique. Geophysics, 61(2), 1947-1957. https://doi.org/10.1190/1.1443966.

Li, X., (2006). Understanding 3D analytic signal amplitude. Geophysics, 71(2), L13-L16. https://doi.org/10.1190/1.2184367.

Miller, H. G., \& Sing, V. (1994). Potential field tilt a new concept for location of potential field sources. Journal of Applied Geophysics, 32(23), 213-217. https://doi.org/10.1016/09269851(94)90022-1.

Nabighian, M. N. (1972). The analytic signal of two-dimensional magnetic bodies with polygonal cross-section: Its properties and use of 
automated anomaly interpretation. Geophysics, 37(3), 507-517. https://doi.org/10.1190/ 1.1440276 .

Pilkington, M., \& Tschirhart, V. (2017). Practical considerations in the use of edge detectors for geologic mapping using magnetic data. Geophysics, 82(3), J1-J8. https://doi.org/10.1190/ geo2016-0364.1.

Roest, W. R., Verhoef, J., \& Pilkington, M. (1992). Magnetic interpretation using the 3-D analytic signal. Geophysics, 57(1), 116-125. https://doi. org/10.1190/1.1443174.

Verduzco, B., Fairhead, J. D., Green, C. M., \& MacKenzie, C. (2004). New insights to magnetic derivatives for structural mapping. The Leading Edge, 23(2), 116-119. https://doi.org/ $10.1190 / 1.1651454$.

Wijns, C, Perez, C., \& Kowalczyk, P. (2005). Theta map: Edge detection in magnetic data. Geophysics, 70(4), L39_L43. https://doi.org/10.1190/ 1.1988184 . 